\title{
МОВНА ГРА ЯК ЗАСІБ АТРАКЩЇ̈ В РЕКЛАМНИХ НАЗВАХ (НА МАТЕРІАЛІ ЕРГОНІМІЇ ТЕРНОПІЛЬЩИНИ)
}

\author{
Деременда Ю. М. Мовна гра як засіб атракції в рекламних назвах (на матеріалі ергонімії \\ Тернопільщини). \\ У статті досліджено роль мовної гри як засобу приваблення клієнта у структурі рекламних назв, \\ вивчено структурні та семантично-асоціативні особливості мовної гри в ергонімії. Виокремлено і проаналізовано \\ моделі ергонімів Тернопільської області, утворених із застосуванням різних прийомів мовної гри.
}

Ключові слова: ергонім, мовна гра, каламбур, атракція, рекламна функція.

Деременда Ю. Н. Языковая игра как средство аттракции в рекламных именах (на материале эргонимии Тернопольской области Украины).

В статье исследована роль языковой игры (каламбура) как средства привлечения клиента в структуре рекламных названий, изучены структурные и семантически-ассоциативные особенности языковой игры в эргонимии. Выделены и проанализированы модели эргонимов Тернопольской области Украины, образованных с применением различных приемов языковой игры.

Ключевые слова: эргоним, языковая игра, каламбур, аттракция, рекламная функция.

Deremenda Y. M. Wordplay as a means of attraction in commercial names (based on company names of the Ternopil region of Ukraine).

The article is a study of the role of wordplay as a means of attraction of clients in the structure of commercial names, of the structural and semantic-associative features of wordplay in ergonymy. It distinguishes and analyzes models of company names of the Ternopil region of Ukraine, which are formed by means of different types of wordplay.

Key words: ergonym, company name, wordplay, pun, attraction, advertising function.

Вільні економічні відносини, які розвиваються в Україні в пострадянський період, викликали зростання ролі реклами як функції ергонімів та пожвавлення інтересу номінаторів і дослідників ергонімії до рекламного потенціалу цих онімів. Серед найдієвіших засобів приваблення клієнта в ергонімії $\epsilon$ незвичність і загадковість ергонімів. Рекламний ефект незвичності в ергонімії досягається за допомогою використання багатьох загальномовних стилістичних засобів підвищення експресивності, серед яких В. Чабаненко називає, зокрема, засоби стилістичного оформлення мовних елементів, наприклад, розтягування звуків, алітерація, асонанс, розбиття слова на склади, трансформація усталеної форми, транспозиція граматичних категорій; стилістичні фігури, як-от: каламбур, еліпс, градація, антитеза, оксиморон; тропи, зокрема гіпербола, метафора, метонімія, перифраза тощо [11 с. 10]. На думку Н. Лєсовець, «семантичний зсув в ергонімі створює гру слів, привертає увагу своєю оригінальністю, несподіваністю» [4, с. 34]. Поряд із різними типами складних слів Г. Зимовець розглядає також деякі випадки телескопії, говорить, що «їхня поява $\epsilon$ одним із проявів мовної гри - поширеної на сучасному етапі стратегії комунікації» [2, с. 32].

Усі наведені вище обставини зумовлюють актуальність нашого дослідження. 3 огляду на важливість мовної гри як засобу реклами в ергонімах і на іiі підвищену експресивність слід визнати, що цей тип ергонімів потребує детальнішого вивчення. Метою нашої статті є глибше 
вивчення прийомів мовної гри як засобів реалізації рекламної функції в ергонімії. Відповідно до цієї мети ми ставимо перед собою завдання дослідити і класифікувати ергоніми Тернопільщини за ознакою наявності в них різних прийомів та різновидів мовної гри.

I. Морозова говорить, що гра слів $є$ одним із найпоширеніших прийомів творення рекламного тексту. Систематизуючи методи і прийоми мовної гри зі значеннями слів і словосполучень, учена виділяє такі базові техніки, як каламбур, слова-«матрійки» та використання стійких виразів (фразеологізмів) [5, с. 70]. Дослідниця називає такі три вимоги до мовної гри як ефективного засобу реклами: 1) значущість (гра слів повинна містити слово, яке позначає значущу рекламну одиницю, що допоможе назві виконувати іiі функції реклами); 2) виправданість (значення каламбуру повинно відповідати об'єкту реклами; так, якщо вдається знайти омонім, то не слід використовувати його задля самого прийому каламбуру, коли він руйнує значення назви); 3) сприйняття (мовна гра має бути зрозумілою для цільової аудиторії) [5, с. 71].

Дослідниця Т. Романова звертає особливу увагу на сучасну тенденцію до створення рекламних назв каламбурного типу, таких, як слова-матрійки, акроніми з подвійною мотивацією, а також граматичні й семантичні каламбуризми, коли ергоніми поєднують у собі двопланову семантику як елемент мовної гри, що «сприяє підвищенню рівня діалогічності рекламної назви, яка має особливе значення для реалізації назвою рекламної функції» [7, с. 211-212]. Дослідниця рекламної номінації вивчає лексичні, морфологічні, стилістичні, граматичні і графічні засоби реклами та виокремлює ряд найдієвіших способів словотвору, що використовуються в рекламній номінації, серед яких називає засоби мовної гри, а саме:

- ініціалізація, тобто використання буквених позначень і назв літер «як елемент інтригуючої мовної гри або просто як оригінальний графічний засіб виділення назви на загальному фоні» [7, с. 210];

- зрощення, тобто об'єднання в одне слово і субстантивацію окремо оформленого словосполучення, що $\epsilon$ «ігровою технікою створення цілісного ергоніма, яка покликана пробуджувати інтерес до назви, а за нею і до самого об'єкта номінації» [7, с. 211];

- сегментація, тобто поділ цілого слова на частини задля надання йому нового, рекламного змісту, що можна розглядати як різновид графічного каламбуру, оскільки «завдяки обіграванню форми виходять слова 3 подвійною мотивацією» [7, с. 211];

- графічний каламбур, тобто обігравання внутрішньої форми слова за допомогою графічного виділення у слові компонента, пов'язаного 3 об’єктом реклами (комп'ютерний клуб «КамЧАТка»);

- граматичний каламбур, тобто цілеспрямоване утворення ергоніма 3 подвійним значенням, внутрішня форма якого сприймається одночасно і як речення, найчастіше спонукальне, і як іменник («Проростай»); 
- семантичний каламбур 3 ігровою семантикою, що створюється за допомогою заміни певного компонента слова для відображення об'єкта номінації, унаслідок чого видозмінюється і переосмислюється внутрішня форма (магазин «Твійдодірок») [7, с. 211-212];

- стилізація і персоніфікація. У таких ергонімах, утворених у результаті стилізації, «відбувається персоніфікація бренду і, таким чином, у підкреслено ігровій формі реалізується традиція називання фірми іменем власника, який особисто відповідає за якість. При цьому в ролі продуктивної основи обирається назва об'єкта реклами або його характеристики» [7, с. 212]. Науковець наголошує, що стилізація та персоніфікація можуть торкатися назви продукту, прізвища власника, вигаданого прізвища і навіть фразеологізмів [7].

T. Романова також звертає увагу на те, що «графічне оформлення ергоніма часом буває супровідним засобом створення рекламного ефекту» [6, с. 35]. Аналізуючи журналістський дискурс у системі культури, С. Сметаніна приходить до висновку, що поширеним засобом, який використовується в рекламному тексті, є графічна гра (або графічний каламбур), який виявляється у «шрифтовій, кольоровій, просторовій, пунктуаційній (лапки, дужки, тире, дефіс) актуалізації елементів, що організують нове слово» [8, с. 204], та що суть графічної гри полягає у виділенні тієї частини слова, яка має сприйматися як активний елемент актуалізатор оригінального смислу [8, с. 205].

За спостереженнями А. Овруцького, здебільшого графічно виділяють назву товару / фірми; таким чином в одному слові поєднуються два або більше різних, але пов’язаних смисли, і така компресія смислу, по-перше, забезпечує кращу запам'ятовуваність рекламної фрази, по-друге, економить дорогий рекламний простір і час, i, по-третє, створює «ефект задоволення» для адресата від декодування оригінального смислу [1, с. 81].

Серед ергонімів Тернопільщини ми виявили такі моделі мовної гри:

1) комбінування мотивуючих лексем чи їхніх частин у лексемусимвол: «Три-тон» (оперативна поліграфія; реклама: тритон - земноводна тварина; у поліграфії друк здійснюється на основі трьох тонів-кольорів).

На письмі таке комбінування мотивуючих лексем (частин лексем) як модель гри слів може реалізуватися за допомогою використання таких засобів графічного оформлення:

а) велика літера: «ТюльПан» (салон гардин: у назві рослини виділені слова тюль - прозора сітчаста тканина, яку використовують для фіранок, i $n a н$ - ввічлива форма згадування або звертання до осіб чоловічої статі);

б) дефіс: «Брук-Тон» (бруківка, бетонні огорожі: бруківка + бетон; суфікс «тон» вживається в назвах міст), «Mi-Ледi» (салон танцювальної, весільної та вечірньої моди);

в) графічні (цифрові) засоби: «ПРО100 меблі» (дизайн-бюро); 
г) абревіація, часто 3 відокремленням перших літер мотивуючих лексем крапками: «Р.С.Й.В.» (чай, кава: абревіація особових імен власників; рейв - різновид сучасної молодіжної музики, велике молодіжне зібрання), «P.I.O.» (вікна і двері: від імені власника - Ригайло I.․․; Жанейро - місто в Бразиліі), «УX Paдіо» (радіостанція: $y x$ - вигук, що виражає яке-небудь сильне почуття; абр. українська хвиля).

2) доповнення мотивуючих лексем (або лексеми) так, щоб вони набрали форми (графічної чи фонетичної) іншого слова: «Суші-ко» (сушібар: доданий до слова суші суфікс -ко нагадує характерне японське звучання); також з елементами гаплології: «Профісбуд-Kreisel» (магазин: $\underline{\text { профi }}+\underline{\text { oфic }}) ;$ у тому числі «жартівливе утворення псевдоабревіатур» [9, с. 7]: «Юнес-Ко» (будівництво: Юрій Нетриб’юк + компанія; ЮНЕСКО - скор. Організація ООН з питань освіти, науки та культури);

3) «контамінація» [9, с. 7], тобто утворення нового слова чи виразу внаслідок зближення, поєднання частин двох подібних слів, форм, виразів: «КомерСайт» (інформаційно-розважальний портал: комерційний + сайт; мовна гра, заснована на співзвучності зі словом комерсант); також 3 елементами телескопії: «Рекламаркет» (РА: реклама + маркет);

4) утворення 3 мотивуючих лексем (або мотивуючої лексеми) новотворів, що імітують наявні моделі лексем певних класів: «Мебелтон» (магазин меблів: вигадане слово, буквально «меблеве місто», від нім. Möbel - меблі + суфікс «тон», що використовується при творенні назв

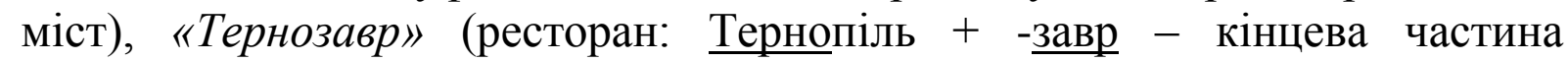
складних слів, що вказує на належність до викопних плазунів, пор. динозавр, іхтіозавр); у тому числі імітація прізвища: «Калганофрф» (алкогольні напої: калган - трав'яниста рослина, корінь якої використовують для лікування шлункових хвороб чи кладуть у горілку, щоб зробити іiі запашною; офф - архаїчний суфікс прізвищ), «Чайкоффф»

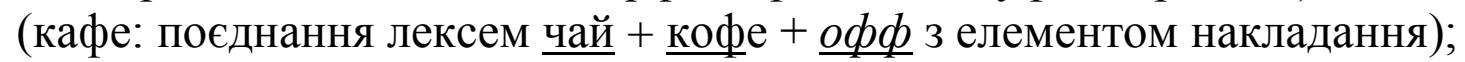

5) «етимологізація стійкого звороту» [9, с. 11]: «Золоте руно» (сувенірна продукція: за старогрецьким міфом, золота бараняча шкура, яку відправились добувати аргонавти; «те, що має найвищу якість, цінність, становить чиє-небудь багатство» [10, с.775]), «П'яте колесо» (автозапчастини; автомайстерня: існує фразеологізм «П’яте колесо до воза» iз негативним значенням «хто-небудь зайвий, непотрібний» [10, с. 385], однак, п’ятим також є запасне колесо, а звідси - автозапчастини);

6) застосування зворотного порядку літер у слові: «Кровтен Сервіс» (комп'ютерний магазин: англ. network, що означає «мережа», прочитане справа наліво);

7) персоніфікація апелятивів, що позначають продукцію підприємства чи саме підприємство: «Пан Баняк» (магазин посуду), «Пані Anтека» (магазин дитячого харчування, медикаментів). 
За відповідністю значеннєвого поля ергонімів характеру позначуваних ними ергооб'єктів Тернопільщини ми поділяємо ергоніми 3 елементами мовної гри на ті, що своїм значенням:

а) відображають інформацію про діяльність закладу: «SAT-EЛIT Cервіс» (супутникове телебачення: у слові cameліт виділено лексему еліт - елітний), «Пані Паляниця» (хлібобулочні вироби: персоніфікація назви товару фірми), «Сорока на хвості» (бізнес довідка: від фразеологізму «Сорока на хвості принесла» про джерело інформації [10, с. 843-844]);

б) відображають інформацію про деякі особливості діяльності об’єкта: «День $i$ ніч» (бар-ресторан: день $i$ ніч - протягом усієї доби, безперервно [10, с. 227]);

в) відображають інформацію про розташування закладу: «Гаїті» (бар: розташований у с. Великі Гаї Тернопільського району), «Новий світ» (КЖЕП; магазин: Новий світ < хоронім-назва мікрорайону < фраз. Новий cвim - Америка, відкрита пізніше, на відміну від Старого Світу [10, с. 784]);

г) переносять на об'єкт свої позитивні конотації: Всеукраїнське аграрне видання "Чим хата багата» (газета), "Ю-кей» (салон вікон і дверей: від імені власника Юрій; імітація фонетичного оформлення абревіатури $U K-$ англ. Сполучене Королівство).

Отже, у результаті аналізу ергонімів Тернопільщини виділено моделі та прийоми мовної гри в ергонімії за природою їхньої атрактивності, визначено типи ергонімів 3 елементами мовної гри за асоціативним зв'язком 3 ознаками денотата. У результаті проведеного дослідження ми зробили такі висновки: гра слів є одним із найцікавіших і найдієвіших засобів реклами в ергонімії; виділені моделі мовної гри в ергонімії демонструють різноманіття прийомів гри слів i доводять важливість подальшого вивчення проблеми.

\section{Література}

1. Анатомия рекламного образа / Под общ. ред. А. В. Овруцкого. - СПб. : Питер, 2004. - 224 с.

2. Зимовець Г. В. Структурно-семантичні особливості ергонімів України / Г. В. Зимовець // Вісник Дніпропетровського університету : Серія : Мовознавство. - № 11. - 2009. - Вип. 15. - Т. 3. - С. $28-33$.

3. Кутуза Н. В. Прийоми мовної гри як мнемонічні техніки та ай-стопери рекламного тексту / Н. В. Кутуза // Мовознавчий вісник : [зб. наук. праць]. - Черкаси, 2009. - Вип. 9. - С. 266-274.

4. Лєсовець Н. М. Засоби реалізації рекламної функції ергонімів / Н. М. Лєсовець // Лінгвістика : [зб. наукових праць]. - Луганськ : Альма-матер, 2008. - №1 (13). - С. 31-36.

5. Морозова И. Слагая слоганы / И. Морозова. - М. : РИН-холдинг, 2006. - 174 с.

6. Романова Т. П. Проблемы современной эргонимии / Т. П. Романова // Вестник СамГУ : Серия : Филология. - 1998. - № 1. - С. 33-38.

7. Романова Т. П. Система способов словообразования рекламных собственных имен / Т. П. Романова // Вестник СамГУ : Серия : Филология. - 2007. - №5/2 (55) - С. 204-214.

8. Сметанина С. И. Медиа-текст в системе культуры (динамические процессы в языке и стиле журналистики конца ХХ века) / С. И. Сметанина. - СПб. : Изд-во Михайлова В.А., 2002. - 383 с.

9. Тимчук О. Т. Семантико-стилістичне явище гри слів в українській мові : автореф. дис... канд. філол. наук: 10.02.01 / НАН України. Ін-т мовознав. ім. О.О.Потебні / О. Т. Тимчук. - К., 2003. - 16 с.

10. Фразеологічний словник української мови : у 2-х томах / Уклад. В. М. Білоноженко, В. О. Винник, І. С.Гнатюк. - К. : Наукова думка, 1993.- 984 с.

11. Чабаненко В. А. Стилістика експресивних засобів української мови : [монографія] / В. А. Чабаненко. - Запоріжжя : ЗДУ, 2002. - 351 с.

Стаття надійшла до редакції 24.11.2011 р. 